\title{
Novas frentes de expansão do complexo imobiliário-financeiro em São Paulo
}

\author{
New urban sprawl vectors of the real \\ estate-financial complex in São Paulo
}

Paula Freire Santoro Raquel Rolnik

\section{Resumo}

Este artigo investiga a participação de agentes globais no complexo imobiliário-financeiro em São Paulo, compreendidos como fundos de investimento e empresas transnacionais especializadas no setor imobiliário que adentram mercados financeiros para diversificar ativos e mitigar riscos, e também como forma de acessar localizações geográficas, criando frentes de expansão. Pretende desenvolver questões como: (1) Os agentes globais e o capital internacional estão penetrando o complexo imobiliário-financeiro em São Paulo? De que forma? (2) Como esse capital se espacializa? Ele cria novas frentes e produtos imobiliários, morfologias e tipologias? Sua ação resulta em processos de reestruturação territorial? (3) Como sua lógica espacial dialoga com os processos de remoção e relocação involuntária? Para responder tais questões, mapeou ativos imobiliários, encontrando, dentre outros, uma nova frente de expansão imobiliária junto ao Rodoanel.

Palavras-chave: complexo imobiliário-financeiro; fundos de investimento imobiliário; companhias imobiliárias globais; capital internacional; expansão urbana.

\begin{abstract}
This article approaches the participation of global players in the real estate-financial complex in São Paulo. Global players are defined as investment funds and transnational companies specialized in real estate that enter financial markets not only as a way to diversify assets and mitigate risks, but also to enable their action in geographical locations, creating sprawl vectors. The article intends to discuss the following questions: (1) Are global players and international capital penetrating the real estate-financial complex in São Paulo? How? (2) How is this capital spatialized? Does it create new urban sprawl vectors and real estate products, morphologies and typologies? Does its action result in territorial restructuring processes? (3) How does its spatial logic interact with involuntary dispossession and relocation processes? To answer these questions, the article mapped global players' real estate assets and found a new urban sprawl vector at the Rodoanel.
\end{abstract}

Keywords: real estate-financial complex; real estate investment funds; global real estate companies; international capital; urban sprawl. 


\section{Introdução: agentes globais na constituição do complexo imobiliário financeiro}

No contexto político-econômico em que se insere o momento atual, definido por Harvey (2014) como a era da hegemonia das finanças, do capital fictício e da supremacia da extração de renda sobre o capital produtivo, a financeirização, ou seja, "o domínio crescente dos atores financeiros, mercados, práticas, medidas e narrativas, em várias escalas, resultando em uma transformação estrutural das economias, empresas (incluindo instituições financeiras), Estados e famílias" (Aalbers, 2015), tem tomado um papel central também nos processos de reestruturação territorial. Para analisar esse imbricamento entre as esferas da financeirização e da transformação do espaço, diversos trabalhos têm destacado a importância de uma leitura associada do circuito financeiro ao imobiliário, constituindo o que Aalbers define como "Complexo Imobiliário-Financeiro"1 (Harvey, 1989; Aalbers e Fernandes, 2016; Rolnik, 2015; Fix, 2007; entre outros).

Como parte desse processo, no Brasil e no mundo assistiu-se a uma veloz reestruturação do Estado e das formas de regulação dos mercados, envolvendo a criação e o aperfeiçoamento de vários instrumentos urbanísticos e financeiros, voltados para aproximar e ampliar as conexões entre capital financeiro e capital imobiliário, conquistando, inclusive, territórios em cidades sob governos de "esquerda", e impondo sua lógica sobre o destino dos lugares, ao submeterem as definições das formas de uso e características de ocupação às necessidades de rentabilidade desses ativos (Rolnik, 2015).

0 complexo imobiliário-financeiro tem articulado essa interdependência entre o setor imobiliário, as finanças e o Estado, espaIhando-se por diversas frentes de expansão imobiliária pelo mundo. Em algumas dessas regiões, já pesquisadas por Aalbers, essa articulação conta com a ação dos chamados global players - ou agentes globais: fundos de investimento e empresas imobiliárias transnacionais que adentram mercados financeiros como forma de diversificar ativos e mitigar riscos, mas também para penetrar em localizações geográficas onde não têm presença, capilarizando-se territorialmente e submetendo a produção das cidades a sua lógica financeirizada (Aalbers, 2014).

Entretanto, não é evidente como essa dinâmica se dá no Brasil, e tampouco o seu papel nos processos de reestruturação espacial em curso no País. Surgem, então, algumas questões que modelam as análises que se estabelecerão ao longo dos próximos itens deste artigo: os global players estão penetrando no complexo imobiliário-financeiro brasileiro e, especialmente, em São Paulo? Se sim, quem são e como se dá essa entrada? Como esse capital se espacializa? Cria novas frentes de expansão imobiliárias? Cria novos produtos imobiliários, com tipologias e morfologias específicas? Como a sua lógica espacial dialoga com processos de remoção e relocação involuntária? 


\section{Financeirização no Brasil: marco regulatório e especificidades}

A conexão entre capital financeiro e imobiliário no Brasil, e principalmente em São Paulo, foi se estruturando no País a partir da década de 1990, o que coincidiu com a implementação de instrumentos urbanísticos que deram subsídio para que a ação dos investidores nesse ramo se tornasse interessante em algumas porções do território, tendo em vista as perspectivas de rentabilidade que movem o mercado de capitais. Esses instrumentos urbanísticos serão retomados mais adiante neste artigo. Entretanto, alguns marcos regulatórios foram essenciais para a constituição de ativos imobiliário-financeiros e de estruturas que articulam esses ativos com o capital internacional, como fundos de investimento imobiliários (FIls), bem como empresas que agenciam esse mercado de ativos - como, por exemplo, as que administram os Flls ou as que compram e revendem Certificados de Potencial Adicional de Construção (Cepacs) - em uma criação paulatina de mercado especializado nesses produtos. Para compreender o objeto dessa frente de pesquisa, ou seja, os global players e sua ação no território, foi necessário adentrar esse marco regulatório e, especialmente, os pontos ligados à criação dos ativos imobiliário-financeiros, pautados nos itens abaixo:

- a criação dos Fundos de Investimento Imobiliários (FIls), em1993, que foi seguida de uma série de instruções da Comissão de Valores Mobiliários (CVM) para sua regulamentação. Os Flls foram utilizados, inicialmente, com o objetivo de captar recursos, principalmente dos fundos de pensão, para empreendimentos imobiliários, tornando-se, apenas depois, alvo de interesse de outros investidores cujas práticas se repercutem na dinâmica territorial urbana (Sanfelici, 2017; Fix, 2009; Botelho, 2007).

- A criação do Sistema Financeiro Imobiliário (SFI), em 1997, que permitiu a participação de instituições financeiras nas operações de financiamento de imóveis, oferecendo, ao investidor, a garantia da alienação fiduciária e a possibilidade de captação de investidores institucionais, como fundos de pensão e bancos de investimento, e também do mercado secundário de recebíveis imobiliários, através de instrumentos financeiros "inovadores", como o Certificado de Recebíveis Imobiliários (CRIs), as Letras de Crédito Imobiliário (LCls) (Royer, 2014; Eloy, 2015);

- A reorganização, na década de 1990, dos fundos de pensão, aumentando o percentual de recursos que poderiam ser investidos no mercado de capitais imobiliários, em especial fundos imobiliários, debêntures e instrumentos financeirizados, como recebíveis imobiliários, entre outros. Em São Paulo, grande parte das pesquisas que mostraram a presença dos fundos de pensão financiando a transformação urbana analisa as mudanças urbanas ao longo do rio Pinheiros, da região no entorno da Avenida Luis Carlos Berrini (Brooklin, zona Sul de São Paulo), determinantes para o boom de torres corporativas, shoppings e hotéis. Nobre (2000) afirma que a entrada dos fundos de pensão no mercado imobiliário paulistano e a mudança na estratégia das empresas - que, em vez de construírem e imobilizarem suas sedes próprias, passaram a ser locatárias de lajes ou edifícios de contratos de longa duração - foram determinantes para esse boom. Segundo 
o autor, entre 1984 e 1999, foram lançados mais de 800 mil metros quadrados de edifícios corporativos, com forte participação do Previ, Funcef, Sistel e outros fundos de pensão (ibid., p. 523). A presença dos fundos de pensão nesses edifícios foi possibilitada em face das alterações de regulação destes que inicialmente viabilizaram e ampliaram a participação dos fundos em ativos imobiliários. Vale lembrar, entretanto, que, embora a ação dos fundos de pensão tenha sido muito significativa durante a década de 1990, nos anos 2000 ela foi se retraindo, segundo Botelho (2007), como reflexo de uma política federal de captar recursos desses agentes para investimento em infraestrutura, que limitou as porcentagens disponíveis para a ação em bens imobiliários.

- A reorganização do Fundo de Garantia por Tempo de Serviços - FGTS nos anos 2000 mostrou a tendência de investir crescentemente em outras aplicações - títulos da dívida pública, FIls, debêntures, CRIs e, notadamente, os empréstimos via FI-FGTS -, ampliando os recursos utilizados com títulos mobiliários. No entanto, Rolnik (2015) procura mostrar que a destinação de seus recursos - que esteve historicamente associada aos interesses estatais - voltou-se, nos anos 2000, assim como os fundos de pensão, para os grandes projetos de infraestrutura, viabilizados através do Fundo de Investimento do FGTS - FI-FGTS, criado em 2007, atraindo, inclusive, os recursos que seriam utilizados em outros títulos mobiliários.

A estrutura financeira que se constituiu a partir desses eventos ficou menos exposta às oscilações do mercado financeiro especulativo internacional se comparada a outros países, já que, embora estivessem disponíveis instrumentos como os CRIs, não se avançou na securitização do crédito habitacional, e a financeirização mais próxima à que ocorre nos países de capitalismo avançado ficou concentrada no setor imobiliário não residencial. Entretanto, se, por um lado, isso fez com que se evitasse o estabelecimento de situações de alto risco, como a que gerou as bolhas hipotecárias da habitação dos EUA e da Espanha, por outro, implementou-se um modelo conservador para a produção habitacional, no qual os grandes players da financeirização não foram agentes privados, mas sim os fundos de pensão e o FGTS.

Em decorrência da adoção desse modelo, foram os fundos de pensão e os paraestatais que assumiram os riscos dos investimentos: como reflexo da crise econômica atual, os fundos de pensão fecharam o ano de 2015 com um aumento de $151 \%$ no déficit e um rombo de 77,8 bilhões de reais, segundo a Previc (Superintendência Nacional de Previdência Complementar). Mais de $60 \%$ desse déficit concentra-se em três grandes fundos: Previ - fundo dos funcionários do Banco do Brasil, Petros - Petrobrás - e Funcef - Caixa Econômica Federal ( $O$ Estado de S.Paulo, 2016); e todos eles se encontram sob investigação, pois há irregularidades na ação de empresas vinculadas a eles, a exemplo da Sete Brasil, criada para fornecer sondas para a Petrobrás e hoje à beira de pedir recuperação judicial em função das investigações.

0 cenário repete-se com os investimentos de infraestrutura do FGTS que, nesse momento de recessão econômica, iniciam um movimento de retração, o qual se agrava em função dos escândalos de corrupção na contratação dessas obras, uma vez que as empreiteiras envolvidas estão listadas na Operação Lava Jato, investigação em andamento pela Polícia Federal do 
País que vem deflagrando, desde 2014, diversos esquemas de corrupção e lavagem de dinheiro envolvendo as maiores empreiteiras brasileiras e empresários - como OAS, Galvão Engenharia, Engevix, Camargo Correa e UTC, Odebrecht e Andrade Gutierrez -, diversas empresas públicas - dentre elas destacam-se a Petrobrás, a Eletronuclear, entre outras -, e partidos políticos - como o PT, PP, PMDB, PSDB, entre outros.

Contudo, a partir do momento em que os "principais motores" da financeirização brasileira passam a enfrentar um esgotamento de recursos e têm suas atividades limitadas diante dos processos de investigação que os envolvem, ações e empresas vinculadas a eles têm seus valores reduzidos, o que passa a atrair investidores internacionais que compram os ativos antes que seja retomado o crescimento nos preços. Um exemplo relevante do uso desse tipo de estratégia é o da transnacional Blackstone, que tem pautado seu crescimento na compra de pacotes de "pechinchas" imobiliárias em vários países e abriu um escritório em São Paulo em 2015 (Portal Uol Economia, 2015) no auge da crise econômica do Brasil. 0 que ocorre é que o risco mais alto inerente a esses ativos vem acompanhado de uma perspectiva de rentabilidades maiores ao longo do tempo, o que pode se colocar como uma ótima oportunidade para atores que possuem um grande volume de recursos disponíveis para investimento.

\section{Desafios "to follow the money"}

Vimos, na seção anterior, que, embora a financeirização no Brasil tenha estado, ao longo das últimas décadas, apoiada principalmente em grandes fundos de pensão e no FGTS, a ação dos global players passa atualmente por um processo de expansão e de diversificação de seus eixos de atuação, já que, com a crise econômica, têm ganhado um espaço que antes era pouco ocupado pela esfera privada. Levantamos também a hipótese de que eles penetrem o mercado imobiliário de uso não residencial, através do qual a financeirização já tem gerado impacto nos preços da terra e nas condições de moradia das cidades. Entretanto, na introdução deste artigo, uma das questões norteadores da pesquisa que estavam colocadas apontava para a necessidade de compreender como se dá essa entrada dos agentes globais no complexo imobiliário-financeiro de São Paulo. Ao nos aproximarmos dessa questão, no entanto, deparamo-nos com uma série de dificuldades para desvendar os caminhos dos investimentos, volume de recursos e beneficiários finais. Ainda assim, foi possível elencar alguns dos mecanismos que têm sido utilizados pelos investidores para trazer capital internacional às transações imobiliárias no Brasil, compreender seu funcionamento e o porquê de serem tão difíceis as investigações mais profundas a seu respeito.

\section{Capital internacional comprou ações das empresas imobiliárias quando da oferta pública inicial - IPO}

No desenvolvimento urbano, vários autores descrevem a diversificação das fontes de recursos disponíveis para seu financiamento, que se expandiram de forma a abarcar recursos obtidos no âmbito financeiro, como foi o caso da abertura de capital de empresas construtoras, conseguindo recursos nacionais e globais 
quando das ofertas públicas na bolsa de valores pela primeira vez, em um processo conhecido como Initial Public Offering - IPOs (Shimbo, 2010, 2012; Sanfelici e Halbert, 2015). É importante destacar que essa forma de financeirização tem sido vista como grande alternativa para captar recursos no setor habitacional (Royer, 2014; Rolnik, 2015; Shimbo, 2010, 2012; Rocha Lima, 2012), que vinha apresentando uma ligação mais tímida com outros mecanismos de financeirização, o que transmuta o caráter da habitação de bem social em direção ao de mercadoria e ativo financeiro (Rolnik, 2015). A captação de valores em 2012, segundo Rocha Lima, representava "pelo valor do patrimônio líquido, quase 8 "gafisas", 4,5 "cyrelas" ou mais de 20 "viver/inpar" (Rocha Lima, 2012, p. 3). Alguns autores apontam que essa estratégia não funcionou - seus empreendedores desconcentraram decisões, caindo em descrédito quanto à sua capacidade de governança, forçaram margens não realizadas, não fizeram boas análises de risco, geraram VGVs sem suporte de absorção do mercado - e, após 2011, as empresas perderam valor, tiveram até mesmo prejuízo ao não conseguirem operacionalizar o crescimento em expansão territorial e novos produtos (segmento popular, por exemplo) que os investimentos exigiram (Rocha Lima, 2012; Sanfelici e Halbert, 2015).

\section{Entrada se dá através dos bancos e fundos de investimentos em participações protegidas pelo sigilo bancário}

No Brasil, investidores estrangeiros podem aplicar seus recursos em quaisquer instrumentos e modalidades financeiras, de acordo com as normas estabelecidas pelo Conselho Monetário Nacional - CMN, que determinam, por exemplo, que o investidor estrangeiro nomeie uma instituição financeira autorizada a funcionar como seu representante fiscal, e esta será a responsável pelo cumprimento das obrigações tributárias decorrentes de suas operações.

Em relação ao Imposto de Renda (IR), o regime tributário é favorável para os investidores estrangeiros que realizam operações financeiro-imobiliárias no Brasil. Estão isentos de ganhos de capital - operações realizadas em bolsas de valores e nas operações com ativos financeiros, e, nos casos em que operam com ativos que estão sujeitos ao pagamento de IR, obedecem às normas aplicáveis aos investidores brasileiros ou, ainda, aplicações financeiras em cotas de fundos de investimento não estão sujeitas a IR.

Um dos primeiros desafios para mapear o fluxo do capital internacional está no fato de estes adentrarem mercado brasileiro geralmente a partir dos bancos, cujas regras de sigilo globais impedem a identificação e a quantificação dos recursos. 0 Chinese Wall é o termo emprestado da intransponível Muralha da China, utilizado pelos mercados financeiros para o mecanismo que protege informações privilegiadas em bancos de investimentos e outras instituições do setor, evitando a circulação de informações estratégicas e confidenciais que possam gerar conflito de interesse. No Brasil, assim como em outros países, é considerado crime o uso indevido de informações não públicas para conseguir vantagem no mercado (insider trading), no entanto, é ingênuo pensar que os gestores de investimento das empresas (asset managers) não se aproveitem dessas 
informações privilegiadas para definir escolhas e oportunidades para seus clientes.

Na esfera da entrada do capital internacional a partir dos bancos, um instrumento comumente utilizado é a formação de FIPs (Fundos de Investimento em Participações) com investidores estrangeiros, que têm como objetivo principal o investimento em empresas tanto abertas quanto fechadas, nos mais diversos setores. Uma das vantagens do FIP para o investidor é sua flexibilidade, tendo em vista que é permitido pela CVM (Comissão de Valores Mobiliários) que a maioria das regras para seu funcionamento seja estabelecida no próprio regulamento do fundo, o que inclui o patrimônio mínimo, a amortização, o prazo do fundo e as políticas de investimento (Campos, 2003), garantindo a diversificação de ativos. Essa flexibilidade permite que o FIP incida na produção de transformação no espaço indiretamente, seja pelo investimento em cotas de outros fundos ligados ao mercado imobiliário (o que também é permitido por sua regulação), seja pela via do investimento em empresas que atuam nesse ramo, segundo o processo descrito abaixo:

a) FIPs compõem Sociedades de Propósito Específico - SPEs

As SPEs são sociedades empresárias que possibilitam a desvinculação de determinada atividade das ações de uma empresa - ou grupo de empresas - num sentido de evitar a contaminação dos outros ativos, caso aquela operação específica não obtenha sucesso, de modo que investidores e compradores fiquem protegidos dos riscos. Esse caráter das SPEs já as torna muito atraentes para a ação dos FIPs, o que é potencializado por outra vantagem tributária: numa empresa comum, a tributação acontece com base em seu lucro real, enquanto numa SPE ela é tabelada e calculada com base num lucro presumido de $8 \%$. A vantagem para o investidor nessa relação está no fato de o lucro real geralmente atingir o patamar dos $20 \%$, ou seja, pagam-se tributos com base numa porcentagem que equivale a apenas $40 \%$ do que de fato deveria ser pago, caso se utilizasse como referência o lucro real (Rocha Lima, 2016).

b) Ações em fundos hedge

Os "fundos hedge" fornecem alto risco ao investidor e, em consequência desse alto risco, um alto retorno. A situação de crise fiscal do Estado, associada à crise político-financeira mais recente no País, com refreamento e deterioração dos negócios imobiliários internos, e a desvalorização cambial têm dado sinais de maior abertura à entrada de capitais internacionais já identificados como global players em outras pesquisas pelo mundo, como já foi citado anteriormente neste artigo. Nesse caso, a atração de investidores internacionais alinhar-se-ia ao que Fernandez (2015) coloca como sendo intervenções pós-crise.

Esse tipo de ação geralmente provém de grandes fontes de recursos, que estão aptas a lidar com os grandes riscos. Grandes fundos imobiliários e empresas como Blackstone, Exxpon e Top Capital, visitam o País em busca de oportunidades imobiliárias que permitam comprar barato, aproveitando-se do período de economia fraca, para lucrar quando o ciclo de retomada chegar. Blackstone, por exemplo, já investiu US\$ bilhões no Brasil em 2015, adquirindo alguns ativos da BR Properties, braço de um dos bancos cujo dono esteve envolvido em escândalo político como Lava Jato, envolvendo corrupção entre Estado e empreiteiras. Muitas dessas grandes empresas têm um plano de investimento em que um percentual 
muito baixo, cerca de $3 \%$, dos recursos são destinados a economias emergentes, dos quais $50 \%$ geralmente são aplicados no Brasil (Rocha Lima, 2016). Por tratar-se de uma porcentagem pequena em relação ao total de ativos da empresa, é vantajoso que se invista em ações de alto risco, já que se ampliam as possibilidades de obtenção de lucro, e não ocorre grande perda, caso a rentabilidade não atinja os níveis esperados.

c) Compras de cotas em Flls - Fundos de investimento imobiliário

Uma outra forma pela qual pode se dar a entrada de capital internacional no complexo imobiliário-financeiro do Brasil é a compra de cotas dos Flls. Como já visto nas análises do marco regulatório, os Flls foram criados na década de 1990 como ferramenta para atrair recursos, com destaque para os de fundos de pensão, como forma de substituição ao crédito inexistente naquele período para a produção de edifícios comerciais (Fix, 2009). Com o tempo, porém, a sua forma de condomínio fechado de investimento, com a possibilidade de organização em cotas a custos acessíveis ao pequeno e médio investidor fizeram com que os Flls conformassem uma boa ferramenta para que se pudesse juntar recursos de diversas fontes menores com o intuito de se atingir um bem imobiliário de maior expressividade do que seria possível caso aquelas fontes atuassem sozinhas (Rocha Lima, 2011). Esse modelo dos Flls foi responsável pela utilização das primeiras emissões de recebíveis imobiliários. Inclusive, por isso, o modelo financeiro brasileiro é tido por Royer (2014) e Fix (2009) como um modelo ainda simples, melhor dizendo, mais restrito, uma vez que os recursos obtidos com a emissão primária de recebíveis imobiliários têm correspondido principalmente a títulos de financiamento de edificações comerciais, mais rentáveis que os habitacionais. Os fundos de investimento imobiliário, compostos pela divisão de cotas negociáveis na Bolsa de Valores, estão entre os primeiros a captar recursos nesse mercado.

Os principais motivos pelos quais pode estar ocorrendo uma entrada de capital internacional via Flls se aproxima aos dos FIPs: há uma série de vantagens tributárias e flexibilizações capazes de potencializar a rentabilidade dos ativos inseridos neles, como a isenção da cobrança de impostos de renda para pessoas físicas sobre seus bens líquidos (lei n. 11.196/2005). Isenções sobre o imposto de renda são uma característica global dos fundos de investimento imobiliário e produtos financeiros semelhantes, associada à possibilidade de competição entre modelos de investimento por investimentos internacionais (Rocha Lima, 2016). No modelo brasileiro, essa característica explica o fato de $88,1 \%$ dos investidores desses fundos serem pessoas físicas, uma vez que a regulação brasileira dá descontos tributários neste caso (Uqbar, 2016). Outro ponto central são facilidade e velocidade da transação de ativos, que, num processo de venda comum, leva cerca de 60 a 90 dias e consome entre 7 e 10\% do valor do imóvel e, no modelo do fundo, segue a alta velocidade do mercado de ações e consome apenas $0,5 \%$ do valor do imóvel, graças a isenções nos impostos e economias nos processos burocráticos de transferência (ibid.).

Embora os Flls brasileiros tenham um funcionamento ainda restrito quando comparado aos internacionais, ${ }^{2}$ sua relevância crescente na transformação do espaço torna-se perceptível quando se analisam os dados 
da Comissão de Valores Mobiliários que demonstram que seu patrimônio total aumentou de 2,4 bilhões em 2005 para 57 bilhões em 2014, representando um crescimento de mais de $2.000 \%$ num intervalo de apenas 9 anos (Botelho, 2007, pp. 169; Rolnik, 2015, pp. 272), e, portanto, é possível considerar a hipótese de que parte desse grande aumento se deva à presença de agentes globais na realização dos investimentos.

\section{Pesquisa exploratória sobre a entrada de agentes globais a partir de duas frentes: mapeamento e tipificação dos ativos de Flls listados pela CVM e das empresas globais com atuação no mercado imobiliário}

Tendo em mente essas diversas formas de entrada do capital internacional nos processos de transformação urbana, e as limitações quanto às possibilidades de acesso à informação em cada uma delas, foi necessário realizar uma escolha na pesquisa para dar seguimento aos seus objetivos. Desenhou-se um segundo eixo norteador que procurou compreender quais as frentes de expansão criadas pela atuação dos agentes globais e quais seriam os produtos, as tipologias e as morfologias geradas nessas frentes. Para realizar essa análise, portanto, era imprescindível analisar a inserção desses produtos no território.

Ainda que fosse impossível quantificar e localizar a aplicação do capital estrangeiro, alguns dos modos de entrada descritos acima permitem que se localizem os bens imobiliários que possivelmente estão ligados a ele. Desse modo, destacaram-se a atuação de empresas globais especializadas no mercado imobiliário e os fundos de investimento imobiliário. Explica-se: muitas das empresas globais disponibilizam portfólios abertos de suas propriedades, no intuito de atrair investidores com os atributos dos ativos oferecidos. Já os fundos de investimento imobiliário são obrigados a seguir vários parâmetros de transparência em seu cadastro na CVM e para sua inserção na Bovespa, o que facilita o acesso aos dados de seus ativos. 0 mesmo não ocorre com os FIPs, que, por não investirem diretamente em bens imobiliários e sim em empresas, acabam tendo sua atividade desvinculada do espaço em uma primeira análise, sendo necessário que se descubram as empresas em que investem para chegar nos produtos, o que é uma tarefa de grande complexidade e que não necessariamente atingiria os objetivos de territorialização esperados.

Foram definidas, assim, as duas frentes exploratórias da pesquisa por meio das quais se produziu o mapeamento que dará subsídio às leituras finais deste artigo. 0 percurso metodológico da realização do mapeamento a partir de cada uma delas será narrado a seguir.

\section{Mapeamento via empresas globais}

Diferentemente dos Flls, as empresas globais que atuam no mercado imobiliário não seguem um padrão bem definido por um marco regulatório no Brasil, e tampouco têm uma organização uniforme entre si. Talvez essa seja uma das razões que fazem com que elas também 
não componham as análises realizadas por instituições especializadas no mercado financeiro, como a Uqbar, que tem produzido relatórios anuais sobre a ação de entidades desse tipo no Brasil, fornecendo dados importantes para a seleção de agentes mais relevantes. $\mathrm{Na}$ ausência desses materiais, e também de fontes oficiais de informação, como os dados que estão disponíveis na CVM a respeito dos Flls, a escolha de quais empresas mapear se baseou numa pesquisa em sites de notícias sobre grandes transações que as envolviam.

A partir dessa pré-seleção, chegou-se a dez nomes: Hines, Blackstone, Brookfield, Global Logistic Properties, Tishman Speyer Properties, Cushman \& Wakefield Properties, Exxon Mobil. Top Capital, Goodman e GP Investments. Restava, então, apurar quais destas mantinham dados de portfólio abertos, de modo que se pudesse mapear suas propriedades. Essa segunda seleção chegou a um conjunto de seis empresas, com uma diversidade de comportamentos significativa:

- Hines - EUA (1957)/ BR (1998) - A Hines é uma empresa do tipo full real-estate, ou seja, que desenvolve uma série de relações diferentes com os imóveis: em cada item de seu portfólio ela pode estar colocada como proprietário, desenvolvedor, gestor de propriedade, gestor de ativos, gestor de instalações, gestor de desenvolvimento, comprador, etc. É importante observar que ela atua em muitos setores diferentes, no que se refere tanto ao uso quanto ao público para que o imóvel se destina. Não se sabe, entretanto, se há alguma estrutura de fundos ligada a ela. Durante o levantamento nos artigos jornalísticos, uma informação central sobre a Hines foi a da compra de cotas da PDG e da Tecnisa no Jardim das Perdizes, um megaempreendimento multiuso inserido na OUC Água Branca, em São Paulo. Sabe-se que o Hines comprou uma participação de 17,5\% no capital social do Jardim das Perdizes, entretanto ele não aparece em seu portfólio. Isso pode, hipoteticamente, decorrer do dinamismo da operação, eventualmente as cotas já foram revendidas, o dado pode estar desatualizado ou, ainda, pode consistir em uma estratégia da empresa de ocultar alguns dados;

- Blackstone - EUA (1985) + Pátria (tornou-se parceira em 2010) - A ação da Blackstone no Brasil é recente e tem enfrentado um crescimento maior nos tempos de crise econômica, com o surgimento de oportunidades de investimento a baixos valores. A atuação da Blackstone em grupo com a Pátria se aproxima bastante à do Hines: o portfólio é composto por propriedades com usos diversificados, e os imóveis também se dividem entre várias categorias de ação por parte do fundo: Buy/Lease, Landbank, Built-to-suit, Sale \& Leaseback, Acquisition, etc. A Blackstone é conhecida por se ligar a diversas empresas parceiras, e a Pátria é apenas uma das que mantêm o acesso a seu portfólio público. Há a possibilidade de mais imóveis - de que não é possível ter conhecimento - estarem vinculados de algum modo à Blackstone em São Paulo;

- Brookfield - EUA (1788) / BR (2000) - A Brookfield é uma das maiores e mais antigas empresas no mercado imobiliário global. No Brasil é composta por vários fundos de investimento, cada um deles especializado em um setor. Há um fundo para shopping centers, um para escritórios, um para residências, um para projetos de infraestrutura e um para investimentos em energia. Essa estratégia de compartimentação facilita a manipulação das 
informações disponíveis sobre a atuação da empresa: alguns dos fundos especializados têm seus portfólios liberados, outros só demarcam que há propriedades, mas não as localizam. Ao conter, além dos investimentos imobiliários, aplicações em infraestrutura e energia, a Brookfield constitui-se como uma das poucas empresas efetivamente privadas de caráter essencialmente financeiro que alocam grande volume de recursos para esses setores no Brasil;

- Global Logistic Properties - Singapore (2003) / BR (2012) - A GLP é uma empresa especializada em galpões logísticos e industriais, que também é composta por muitos fundos, separados por país e forma de atuação. Os fundos atuantes no Brasil são o GLP Brazil Development Partners e o GLP Brazil Income Partners I e II;

- Tishman Speyer Properties - EUA (1978) / BR (2000s) - Ao observar o portfólio da Tishman Speyer, fica nítido que a empresa se foca no mercado de propriedades de alto padrão, sejam elas residências de luxo ou torres corporativas de alta tecnologia. Não está tão claro, porém, se há vários tipos de relação entre essa empresa e os imóveis, e só há uma articulação entre a criação de fundos e relações de propriedade. Um ponto relevante da atuação da Tishman Speyer é o investimento em residências, que dificilmente são vistas como ativo interessante no Brasil por estruturas fincanceirizadas, a exemplo dos Flls. Outra questão central é o fato de vir ocorrendo, a partir da década de 2000, um grande enfoque dessa empresa no investimento em países emergentes, como a Índia e a China, além do Brasil.

- Cushman \& Wakefield Properties - R.U. (1820) / BR (2000s) - A Cushman \& Wakefield também é uma empresa muito antiga no ramo imobiliário com atuação em diversos setores, incluindo a construção e incorporação, mas sua ligação com mecanismos financeiros como fundos imobiliários ou de private equity é tardia, iniciando-se apenas no fim da década de 2000. Diferentemente dos demais portfólios visitados, em que havia maior diversificação de usos, a concentração das propriedades da Cushman \& Wakefield dá-se primordialmente no campo dos escritórios, e outra característica peculiar é o fato de elas serem muito mais fragmentadas: enquanto as demais empresas pesquisadas comumente apresentavam no portfólio conjuntos inteiros, blocos ou até conjuntos de andares, muitas das propriedades da Cushman \& Wakefield são lajes soltas, embora o número de empreendimentos seja muito maior que 0 das demais.

Tendo mapeado os portfólios de todas essas empresas, o resultado foi o mapa (Figura 1), que cobre toda a Região Metropolitana de São Paulo. Todavia, pelas limitações metodológicas descritas anteriormente, o mapeamento não constitui uma leitura fiel quanto à quantificação dos ativos e, tampouco, é completamente precisa sua distribuição em cada uso, de sorte que seu objetivo principal seja a leitura dos padrões de distribuição ao longo do território.

\section{Mapeamento via Flls}

0 mapeamento via Flls deu-se através de um processo mais simples, já que havia uma disponibilidade de dados com os quais as empresas globais não contavam. 0 primeiro passo para esse mapeamento foi acessar e listar os Flls inscritos na Bovespa e na CVM. Depois, cruzou-se a tabela de proprietários e de endereços disponibilizada a partir dos cadastros 
Figura 1 - Ativos imobiliários ligados a empresas globais

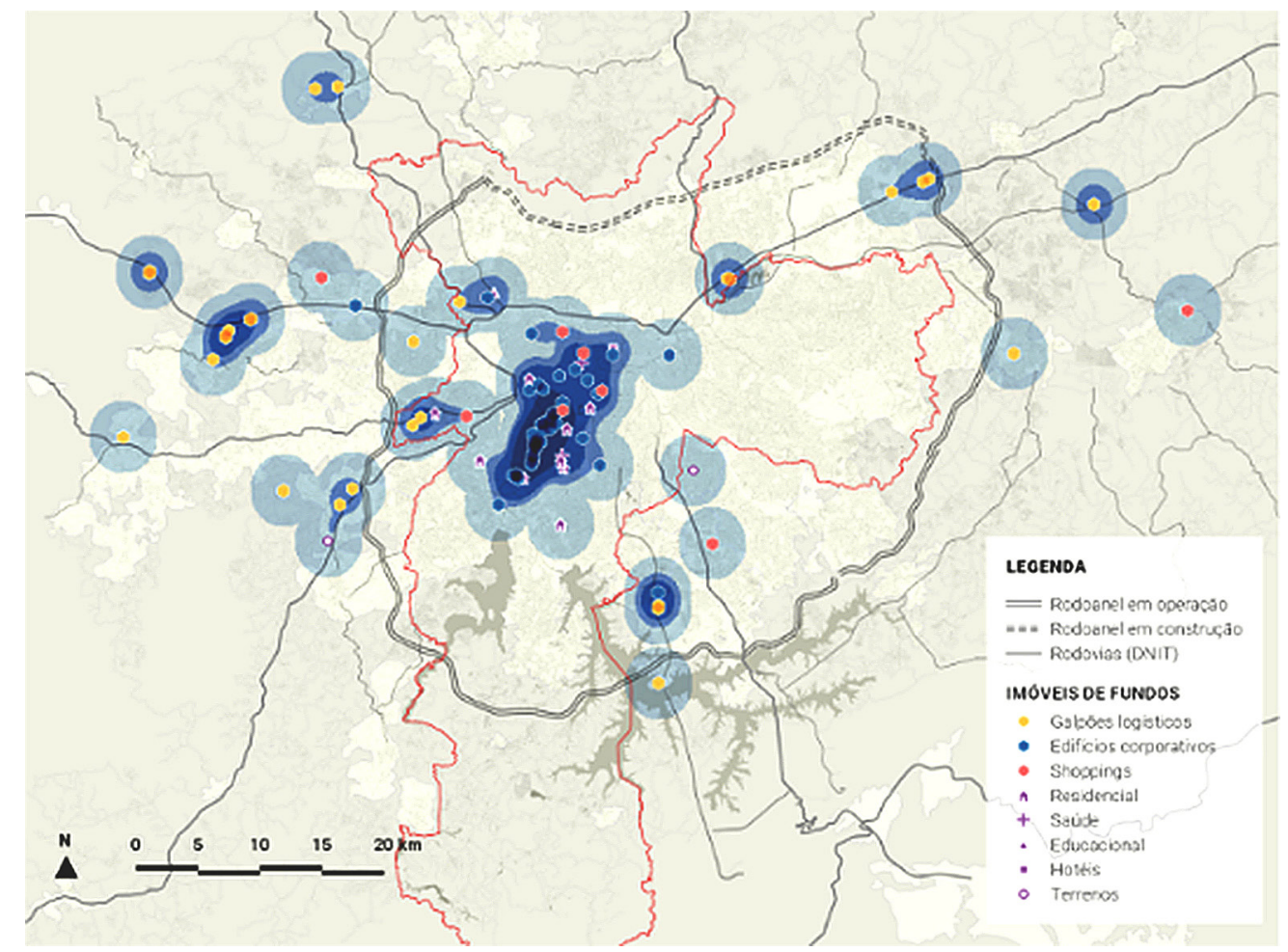

Fonte: Equipe ObservaSP.

do IPTU na cidade de São Paulo com os Flls listados durante a primeira etapa, a fim de obter pontos correspondentes às propriedades dos fundos.

Com isso, obteve-se um mapa que é fiel à distribuição dos fundos até na indicação quantitativa de áreas de laje e usos de seus imóveis. Contudo, ao realizar essa análise em grande escala, perdeu-se a possibilidade de tipificar todos os produtos encontrados, e o enfoque dessa segunda frente, por isso, esteve mais relacionado à aproximação a alguns pontos específicos, com destaque para os que não se encaixavam em nenhuma das categorias de tipificação definidas com as leituras da primeira frente. Outro aspecto importante é o fato de essa segunda frente abranger apenas os limites municipais de São Paulo, pois não há como acessar os dados de IPTU dos demais municípios que compõem a RMSP. Fica destacada aí a importância de um sistema de transparência e acesso a informação para que pesquisas nesse âmbito consigam se efetivar.

Unindo os pontos das duas frentes exploratórias, obteve-se um mapa que agrega leituras de concentração e tipificação dos ativos mapeados ao longo do território. Na próxima seção, serão reunidas algumas das interpretações do grupo de pesquisa acerca dos resultados finais do mapeamento. 
Figura 2 - Ativos imobiliários ligados à Flls

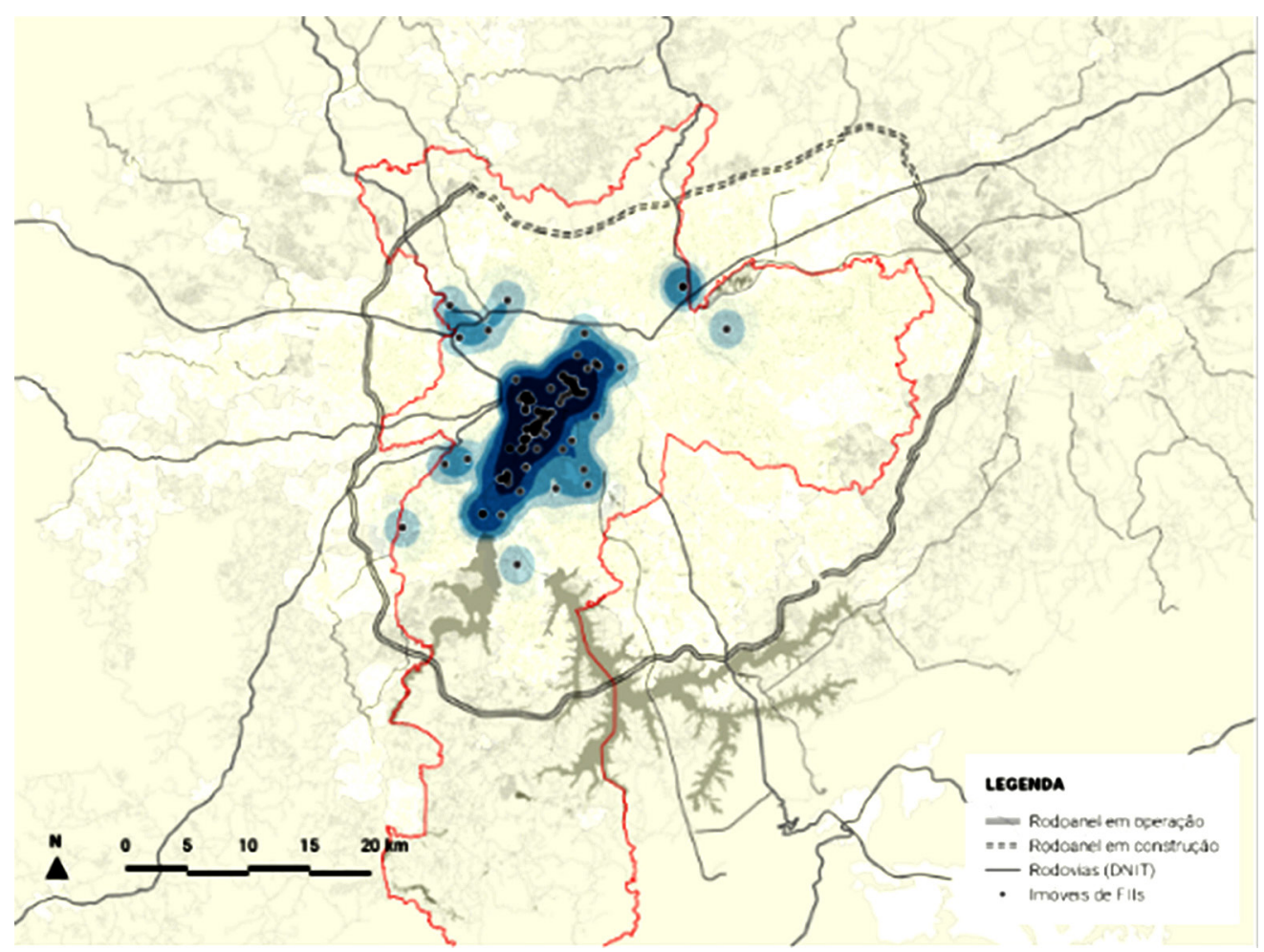

Fonte: Equipe ObservaSP.

\section{Leitura dos dados: diversidade de tipos de ativos}

Olhando para o conjunto de pontos mapeados, ficou evidente a diversidade dos tipos de ativos. Contrariando a noção de que os agentes financeiros só atuam nas frentes tradicionais de shoppings e torres corporativas, foram encontrados hotéis, faculdades, hospitais, agências bancárias, supermercados, equipamentos de logística e terrenos disponíveis para built-to- -suit (principalmente para atividades de logística). Os dados do Anuário Imobiliário Uqbar, de 2016 (ver Gráfico 1) corroboram com os resultados da pesquisa, uma vez que mostra 0 crescimento de outros tipos de ativos no âmbito dos Flls.

Agrupamos as principais descobertas da pesquisa quanto à tipificação dos ativos mapeados em três classificações, conforme seus objetivos e suas particularidades de inserção territorial. 
Gráfico 1 - Composição da capitalização de mercado por tipo de imóvel

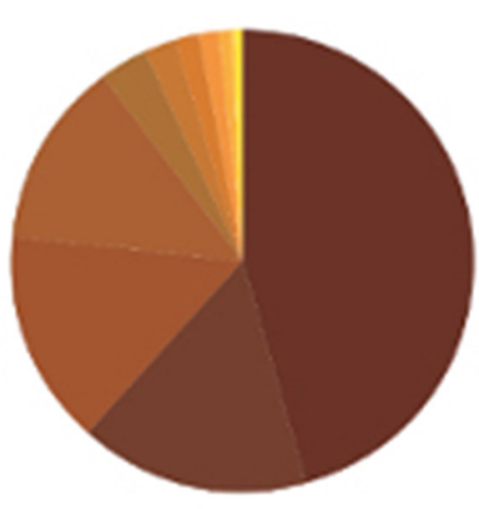

Fonte: Anuário Imobiliário Uqbar (2016).

\section{Concentração nas frentes de expansão "tradicionais" e tipologias reconhecidas pelo capital internacional}

Eduardo Nobre (2000), Mariana Fix (2009), entre diversos outros autores, já vinham sinalizando a existência de uma frente de expansão do mercado imobiliário situada nos arredores da Marginal Pinheiros e da Avenida Luís Carlos Berrini, focado essencialmente em produtos corporativos. A formação de tal eixo de expansão, que vinha se estabelecendo desde a década de 1990 com a ação dos fundos de pensão, é parte de uma agenda de processos de valorização da terra apoiada em instrumentos de reestruturação do espaço implementados pelo

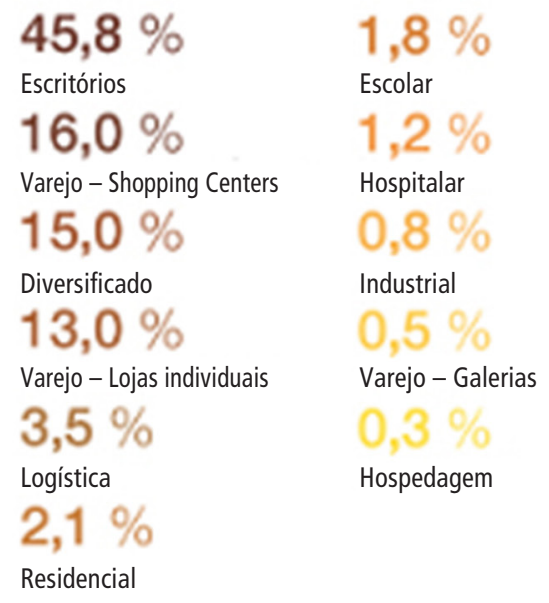

poder público, como as Operações Urbanas Consorciadas Faria Lima e Águas Espraiadas, que implementam uma série de mudanças nos desenhos viários na região do eixo descrito, utilizando, para isso, o capital de companhias interessadas em empreender na região.

O Mapeamento dos Flls e das Empresas globais confirma e reforça a existência desse eixo de expansão com esses mesmos produtos e entende, ainda, que shoppings e hotéis ajudam a compor essa leitura da distribuição espacial dos ativos voltados para um público de alto padrão, focada no quadrante sudoeste da cidade e, especialmente, no eixo Berrini-Pinheiros. 0 que não ficava claro, porém, era o porquê da preponderância desse tipo de ativo em relação aos outros. Em entrevista com 
João Rocha Lima, que trabalha com consultoria de Real Estate e presta assessoria a fundos imobiliários, ficou claro que se trata de uma questão de conhecimento do comportamento dessa tipologia pelos investidores. Segundo ele, a tipologia arquitetônica das torres corporativas de alto padrão e shopping centers é manter uma linguagem que se altera pouco conforme mudam as localizações, e isso possibilita que os investidores, e em especial os investidores estrangeiros, reconheçam nelas um produto já desvendado, que, portanto, gerará expectativas de risco e rentabilidade também conhecidas.

Figura 3 - Empresas globais e tipologia corporativa no eixo da Marginal Pinheiros

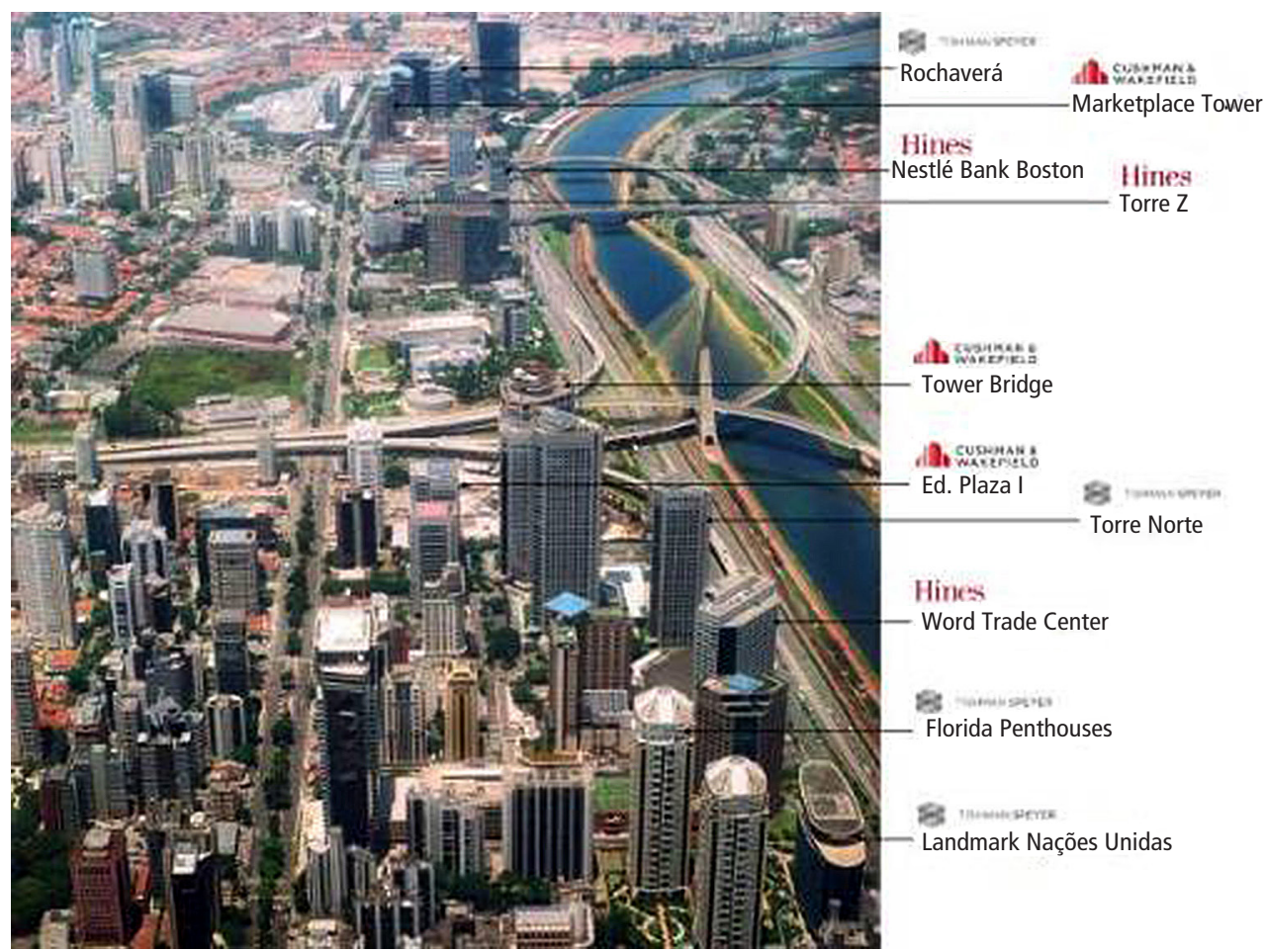

Fonte: Equipe ObservaSP. 
Figura 4 - Ativos no setor corporativo de Flls e empesas globais

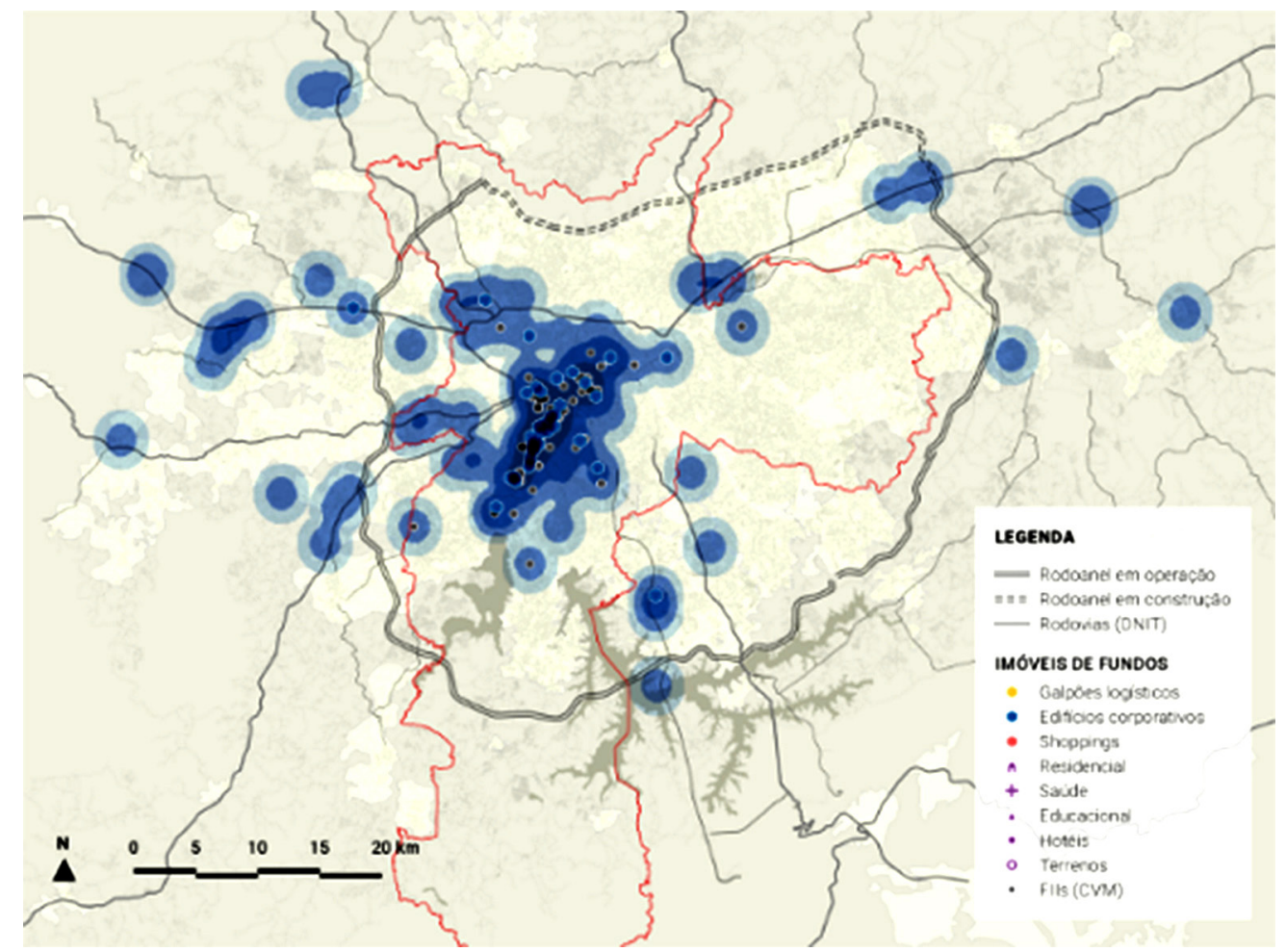

Fonte: Equipe ObservaSP.

Como a transformação nessa região já vinha ocorrendo há bastante tempo, resgatamos um mapeamento do início da década de 1990 (Castro, 2006), quando começaram a ser implementadas as operações urbanas Faria Lima e Águas Espraiadas, para realizar a leitura da ação dos agentes em contraposição com os processos de remoção. 0 resultado mostra que as remoções abriram um espaço para a atuação de agentes financeirizados que se construiria ao longo das décadas subsequentes.
Empresas Globais na desmobilização de ativos e estratégias de isenção tributária

Considerando a reorganização das formas de produção no território, a pesquisa demonstrou que o formato dos fundos imobiliários seria interessante para estruturar a divisão entre operação e manutenção das infraestruturas, desassociando a gestão da atividade produtiva da gestão de imóveis, cujos custos 
de manutenção e depreciação são tidos como desvantajosos e caros. Dessa forma, os instrumentos de financeirização retiram o capital que fica fixo no imóvel para que ele possa circular mais livremente e rapidamente, como exige o fluxo do capital flexível. Estes seriam os casos de desmobilização de ativos.

Essa lógica se insere no âmbito da substituição de um modelo de produção e acumulação calcado na rigidez produtiva para um regime fundamentado em maior flexibilidade de processos, produtos, padrões de consumo, mercados e organização do trabalho (Harvey, 2008). Sinaliza a emergência de novos setores de produção, novas modalidades de serviços financeiros que envolveu a criação de novos mercados (de aluguel de imóveis para supermercados, compondo a rede), com intuito de garantir que o sistema produtivo seja capaz de operar dentro de contextos que exigem rápidas mudanças, adaptando-se continuamente às variações da demanda. No caso, o aluguel possibilita essa agilidade.

Nos mapeamentos, os casos em que entendemos que há um objetivo central de desmobilização de ativos são diversos: há, por exemplo, a vinculação de hospitais e universidades às empresas imobiliárias globais, ou de agências bancárias a fundos de investimentos.

Figura 5 - Ativos corporativos no eixo Berrini x Pinheiros e remoções

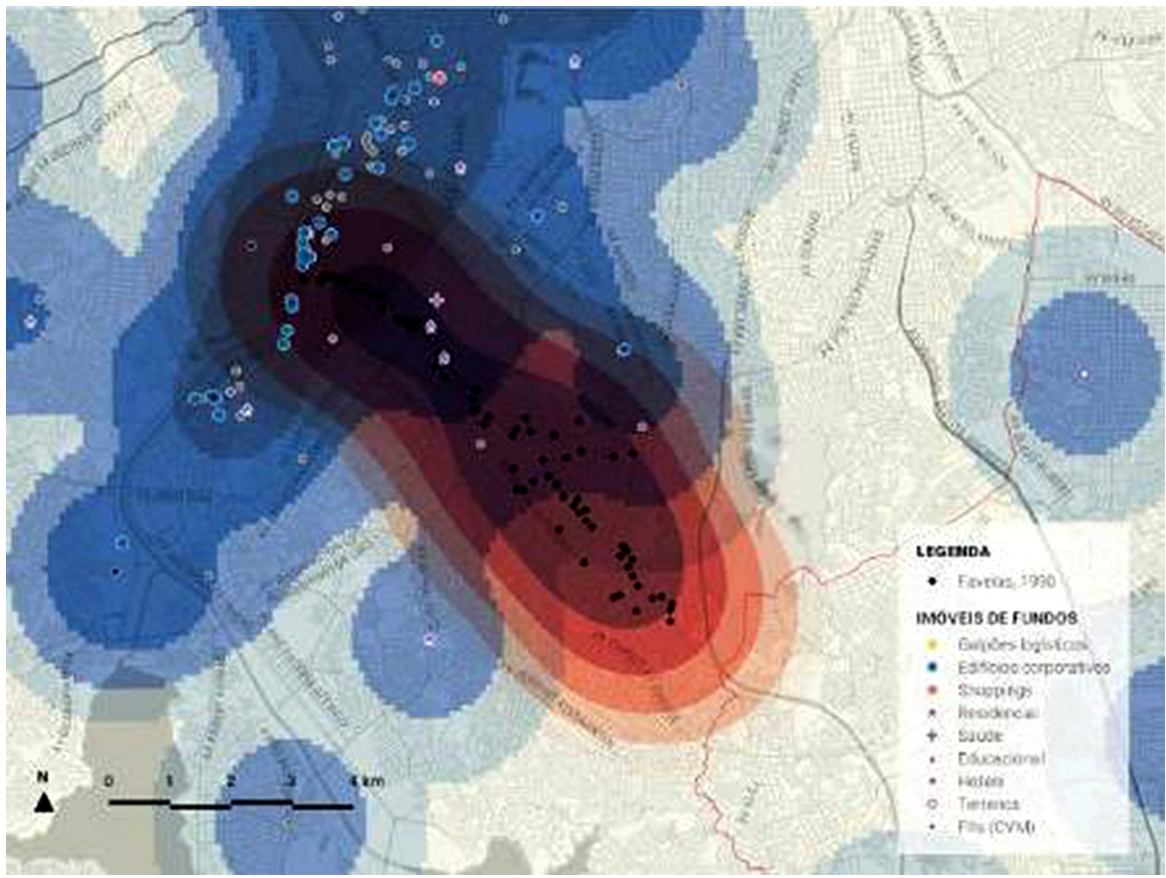

Fonte: ObservaSP sobre base de remoções disponível em Castro (2006). 
Figura 6 - Hospitais vinculados a empresas imobiliárias globais

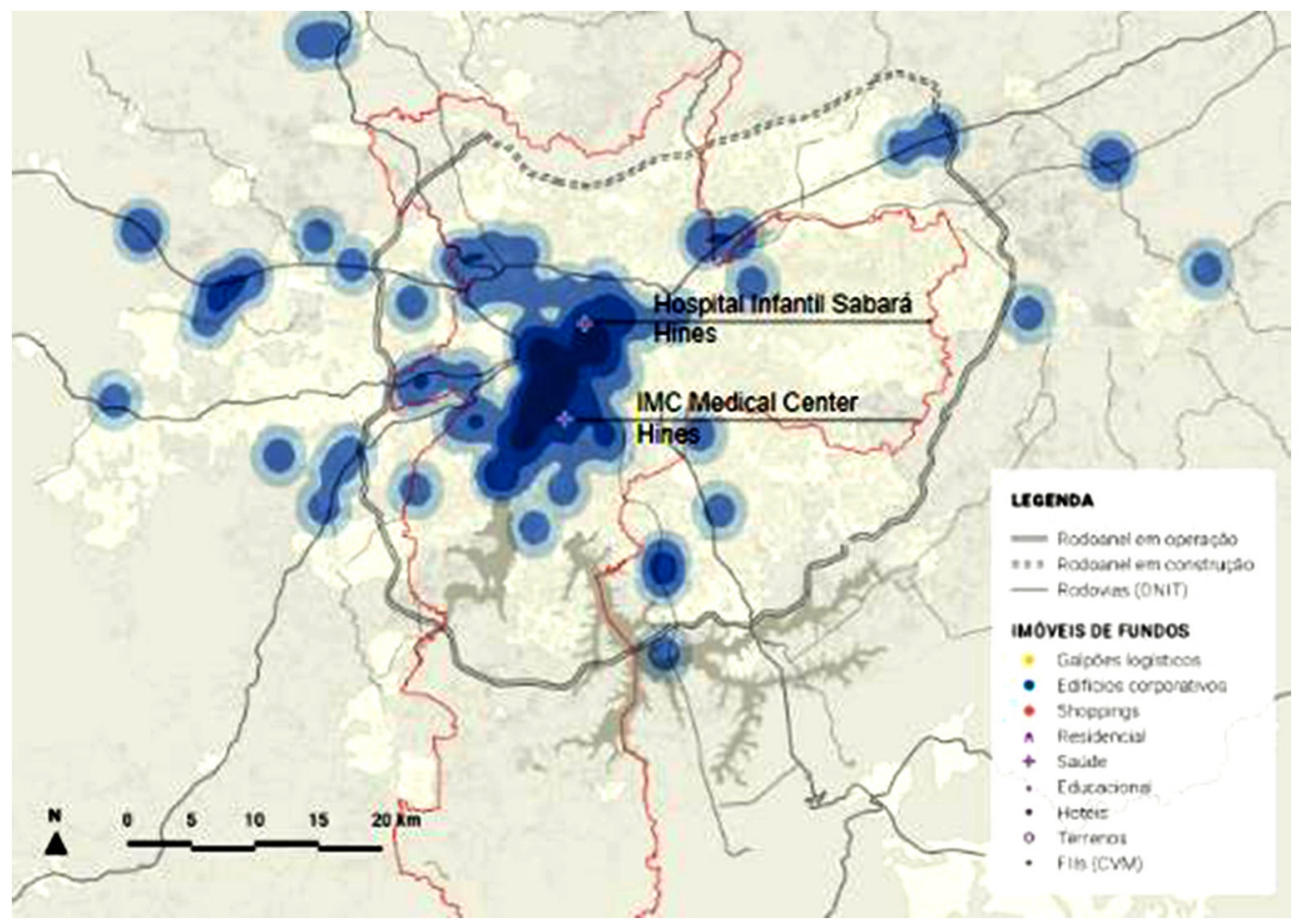

Fonte: Equipe ObservaSP.

Nova frente de expansão do complexo imobiliário- financeiro: logística no Rodoanel

Uma descoberta central atingida a partir do mapeamento realizado no decorrer da pesquisa foi a da constituição de um novo eixo de expansão do complexo imobiliário financeiro, contando com ação de fundos e empresas globais, ao longo do eixo do novo anel viário que está sendo construído em volta da cidade de São Paulo - 0 Rodoanel.
Ao percebermos a existência de muitos pontos com o uso de logística e a tipologia dos galpões built-to-suit nas proximidades do Rodoanel, com destaque para os entroncamentos com outras rodovias que partem da cidade de São Paulo, vimos a necessidade de investigar até que ponto as obras de implantação desse sistema rodoviário estavam articuladas à ação das companhias globais mapeadas. Após a realização de uma aproximação fotográfica a alguns desses casos ao longo do tempo, ficou clara uma enorme sincronização entre a ação 
Figura 7 - Ativos logísticos de companhias imobiliárias globais

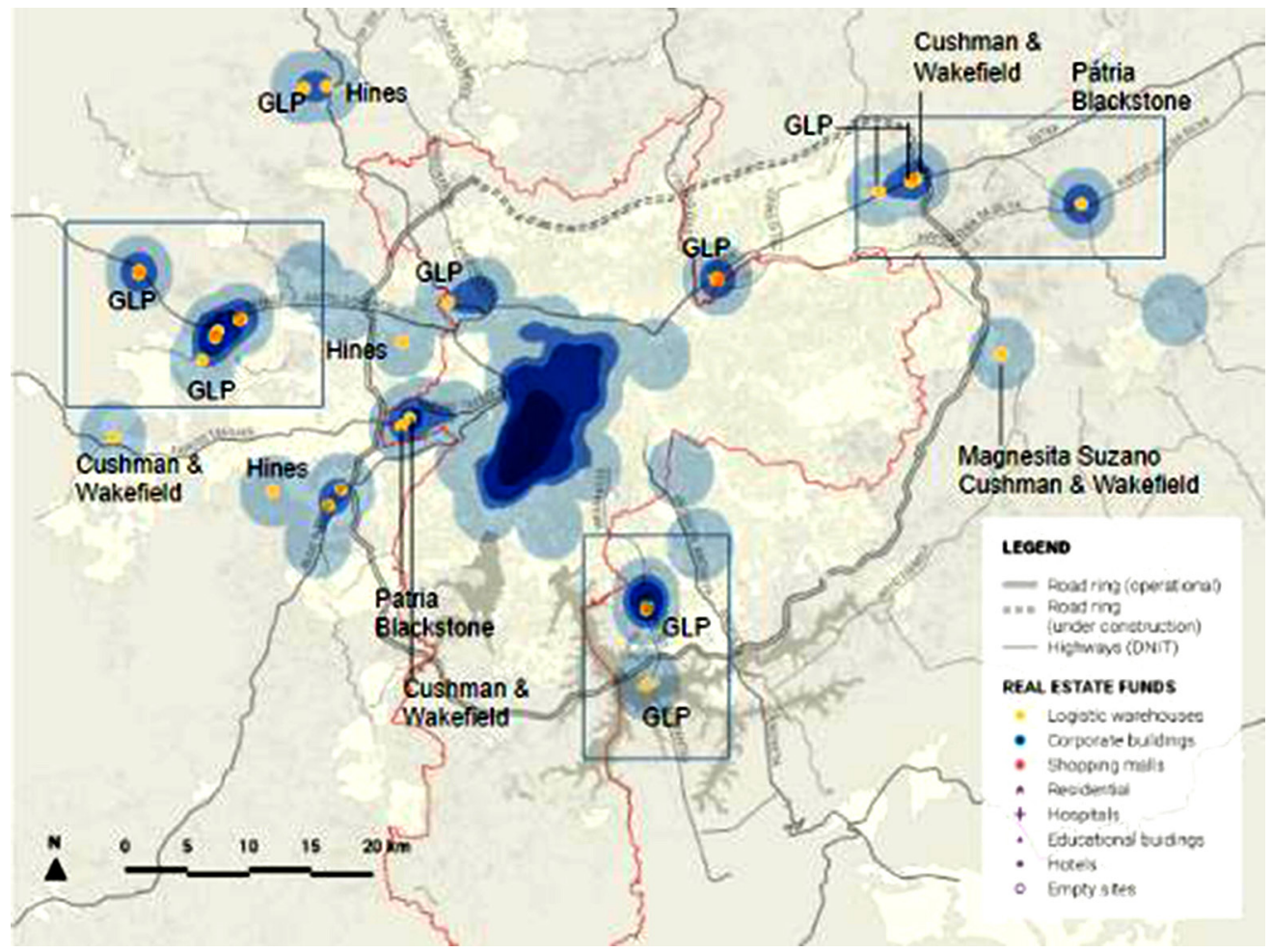

Fonte: Equipe ObservaSP.

do Poder Público, que, por meio de uma Parceria Público-Privada, deu início às obras do Rodoanel, e a construção dos galpões.

A estruturação dessa frente de expansão logística ao longo do Rodoanel com a entrada de agentes globais torna-se ainda mais clara quando tomamos como exemplo a vinda da especializada em logística GLP para o Brasil em 2012, coincidindo com o início das obras dos trechos Leste, no final de 2011, e Norte, no início de 2013. Para além disso, em 2014, a GLP comprou um grande pacote de propriedades logísticas da BR Properties, no movimento de baixa dos preços devido à crise econômica, muitas das quais estão localizados nas proximidades do Rodoanel (Rostás, 2014).

Como em todo processo de valorização de terras que ocorre a partir da criação de uma nova frente de expansão imobiliária, a tendência é que se acentuem, ao longo dessa frente, a segregação socioterritorial e as remoções. Cruzando a ação dos fundos logísticos com o mapa disponibilizado pela plataforma do Observatório de Remoções de 2016, é possível observar que, ainda que se trate de um vetor incipiente, já há uma concentração de ameaças nas proximidades do Rodoanel. 
Figuras 8-11 - Imagens aéreas do entroncamento do rodoanel com a rodovia dos Imigrantes entre os anos de 2004 e 2016
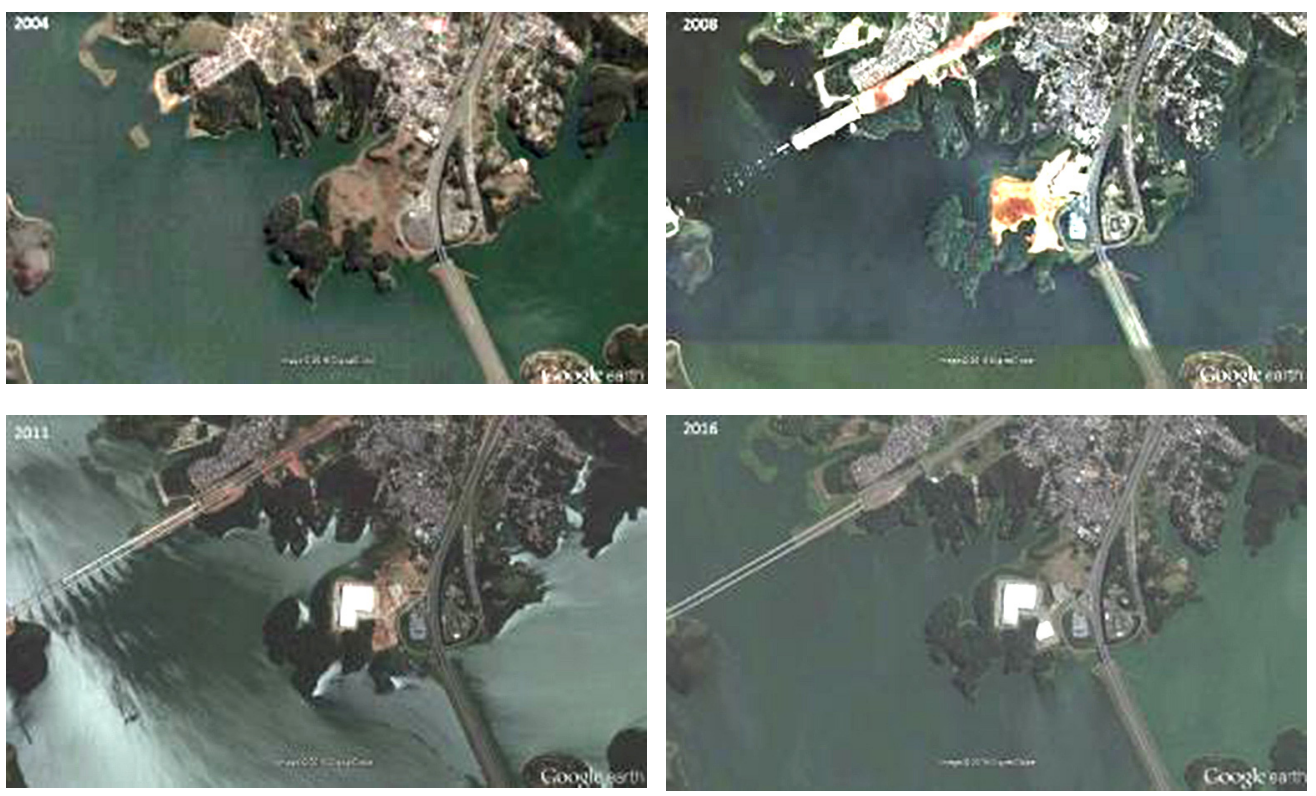

Fonte: Ferramenta de "time lapse" do Google Earth Pro. 
Figura 12 - Remoções e galpões logísticos de empresas globais no Rodoanel

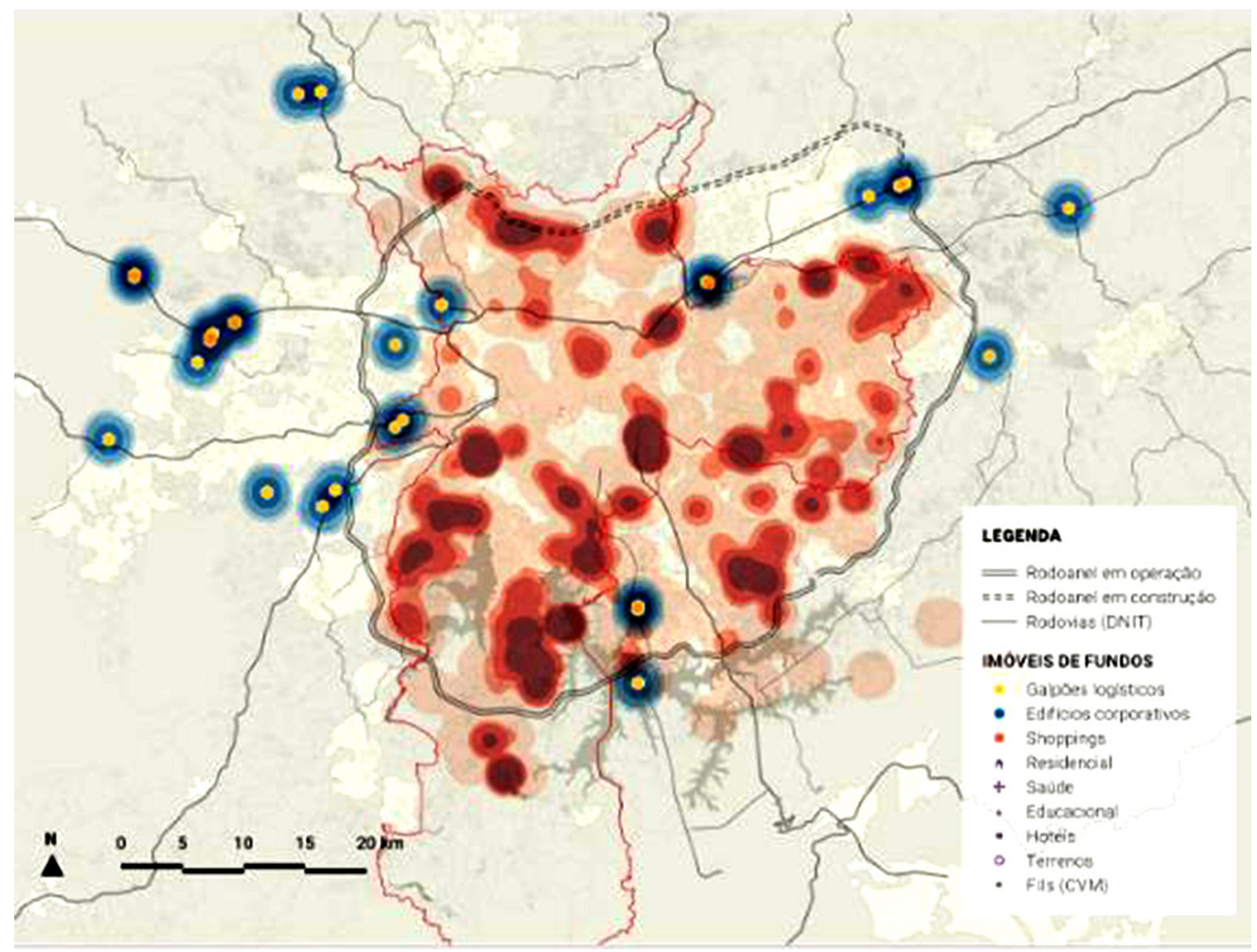

Fonte: Equipe ObservaSP sobre base disponibilizada pelo Observatório de Remoções (2016).

\section{Considerações finais}

Ainda que se tenha enfrentado uma série de barreiras quanto às possibilidades de exploração da entrada dos investimentos provenientes de agentes globais no complexo imobiliário-financeiro de São Paulo, a pesquisa narrada por este artigo conseguiu um avanço muito relevante na territorialização dos ativos de empresas internacionais e fundos que muito possivelmente vêm recebendo investimentos estrangeiros. As descobertas, tanto no que diz respeito ao desenvolvimento de uma metodologia de ação factível e que trouxesse resultados dentro dos limites experimentais, quanto no que tange à revelação de situações das quais antes não se tinha conhecimento, possibilitam a formulação de outras hipóteses e questionamentos, e formam, assim, toda uma nova agenda de pesquisa dentro do tema.

Nesse sentido é importante destacar a visibilização da nova frente de expansão 
imobiliária que vem se desenvolvendo com as obras do Rodoanel em São Paulo, que só foi possível graças à realização do mapeamento numa escala metropolitana, compreendendo o território de maneira articulada, e não fragmentado pelas fronteiras municipais. Surge, com isso, a inquietação de se expandir ainda mais a escala das análises, atingindo o âmbito da macrometrópole, de forma a - quem sabe explicitar outras questões relevantes que estão sendo ocultadas pela adoção de um sistema de compreensão não integrado.

\section{Paula Freire Santoro}

Universidade de São Paulo, Faculdade de Arquitetura e Urbanismo, Departamento de Projeto da Faculdade de Arquitetura e Urbanismo. São Paulo, SP/Brasil.

paulasantoro@usp.br

\section{Raquel Rolnik}

Universidade de São Paulo, Faculdade de Arquitetura e Urbanismo. São Paulo, SP/Brasil. raquelrolnik@gmail.com

\section{Notas}

Isabel Martin Pereira e Pedro Henrique Rezende Mendonça, pesquisadores do Laboratório de Habitação e Assentamentos Humanos, da Faculdade de Arquitetura e Urbanismo, da Universidade de São Paulo, colaboraram com a criação deste trabalho.

(1) Utilizamos aqui a expressão "complexo imobiliário financeiro" no sentido proposto por Aalbers, como uma metáfora inspirada no complexo industrial/militar norte-americano, capaz de chamar a atenção para a relação entre a produção imobiliária, as finanças e os Estados. Ambos os complexos devem ser entendidos como triângulos, uma vez que os Estados também fazem parte dessa equação. A expressão complexo industrial militar foi utilizada, pela primeira vez, pelo então presidente Eisenhower em seu discurso de despedida da presidência em 1961, referindo-se ao triângulo que incluiu contribuições políticas, aprovações de orçamento militares, lobbies para sustentar burocracias e uma rede de contratos e fluxos de dinheiro entre indivíduos, corporações e instituições ligadas a provedores de armas e serviços militares (fonte: Oxford Dictionaries). 
(2) Os Flls têm aspectos semelhantes aos do Real Estate Investment Trust (Reit), ativo securitizado no mercado de valores mobiliários americanos, que tem obrigatoriedade de um percentual mínimo a ser investido em imóveis, um percentual mínimo de distribuição de rendimentos elevados e alíquota baixa ou nula para o imposto de renda, que, no caso brasileiro, dá-se apenas para pessoa física. Possuem uma forma híbrida de se comportar, como uma ação (equity) ou uma renda fixa (que paga coupon ou payout mensal), o que atrai investidores interessados por seu benefício de renda fixa. Diz-se que os Reitss são mais flexíveis que os Flls. Estes últimos, por sua vez, não fomentam a formação de grandes imóveis comerciais (são mais uma partilha de investimento em imóveis) e são um instrumento de funding do próprio investimento (o que não ocorre com os Reits).

\section{Referências}

AALBERS, M. B. (2014). “Corporate Financialization'. In: CASTREE, N. (ed.). The International Encyclopedia of Geography: people, the earth, environment, and technology. Oxford, Wiley.

AALBERS, M. B. e FERNANDEZ, R. (2016). Financialization and Housing: between globalization and varieties of capitalism. Competition and Change, v. 20, n. 2 (mimeo)

ALVES, M. R. (2016). Fundos de Pensão Investigados pela PF respondem por $62,6 \%$ do rombo do sistema em 2015. O Estado de S.Paulo. Disponível em: http://politica.estadao.com.br/noticias/ geral,fundos-de-pensao-investigados-pela-pf-respondem-por-62-6-do-rombo-do-sistemaem-2015,10000074136. Acesso em: 7 set 2016.

BOTELHO, A. (2007). O urbano em fragmentos: a produção do espaço e da moradia pelas práticas do setor imobiliário. São Paulo/Fapesp, Annablume.

CAMPOS, R. (2003). Private Equity no Brasil: Fundos de Investimento em Participações. Disponível em: http://www.migalhas.com.br/dePeso/16,MI2600,11049-Private+Equity+no+Brasil+o+fundo+de +investimento+em+participações. Acesso em: nov 2016.

CASTRO, L. G. (2006). Operações Urbanas em São Paulo: interesse público ou construção especulativa do lugar. Tese de Doutorado. São Paulo, Universidade de São Paulo.

ELOY, C. M. (2013). The brazilian housing finance system: potential do address housing needs and demand: financialization trends. Presentation at Internacional Seminar Parcerias públicoprivadas e o complexo imobiliário-financeiro. São Paulo, LabCidade, FAUUSP. (mimeo)

FERNANDEZ, R. (2015). Gullivers's Travels: the universe of the big numbers of global finance. Apresentação para o curso sobre PPP realizado na FAUUSP em setembro. (mimeo)

FIX, M. (2007). São Paulo cidade global: fundamentos financeiros de uma miragem. São Paulo, Boitempo Editorial.

(2009). Uma ponte para a especulação - ou a arte da renda na montagem de uma "cidade global". CADERNO CRH. Salvador, v. 22, n. 55, pp. 41-64. 
GOMES, A. V.; ROYER, L. de O. e PEREIRA, A. L. dos S. (2013). Mercado de capitais e mercado imobiliário: crescente importância dos títulos de base imobiliária. In: ENCONTROS NACIONAIS DA ANPUR. Anais. Recife, v. 15.

HARVEY, D. (1989). 'From Managerialism to Entrepreneurialism: The Transformation in Urban Governance in Late Capitalism'. Geografiska Annaler, Series B, Human Geography. Suécia, v. 71, pp. 3-17.

(2008). Condição pós-moderna: uma pesquisa sobre as origens da mudança cultural. São Paulo, Loyola.

(2014). Seventeen Contradictions and the End of Capitalism. Oxford, Oxford University Press.

JARDIM, M. C. (2010). Observatório de investimentos na Amazônia: fundos de pensão. Brasília, Inesc.

LEVIN J. et al. (2015). Blackstone compra imóveis no Brasil em meio a aperto no crédito. Artigo jornalístico para portal Uol Economia. Disponível em: http://economia.uol.com.br/noticias/ bloomberg/2015/06/08/blackstone-compra-imoveis-no-brasil-em-meio-a-aperto-no-credito. htm. Acesso em: maio 2016.

NOBRE, E. A. C. (2000). Reestruturação econômica e território: expansão recente do terciário na Marginal do Rio Pinheiros. Tese de Doutorado. São Paulo, Universidade de São Paulo.

PEREIRA, A. L. dos S. (2015). Intervenções em centros urbanos e conflitos distributivos: modelos regulatórios, circuitos de valorização e estratégias discursivas. Tese de doutorado. São Paulo, Universidade de São Paulo.

ROCHA LIMA, J. (2011). Fundos imobiliários têm futuro no Brasil? Carta do NRE-Poli, n 24-11, abriljunho. Escola politécnica da USP, São Paulo.

(2012). Começar de novo: o futuro das companhias de real estate de capital aberto no Brasil. Carta do NRE-Poli, out-dez.

(2016). Depoimento [out. 2016]. Entrevistadores: Isabel Martin Pereira, Paula Freire Santoro, Pedro H. Rezende Mendonça, Raquel Rolnik. São Paulo.

ROLNIK, R. (2015). Guerra dos lugares: a colonização da terra e da moradia na era das finanças. São Paulo, Boitempo.

RONALD, R. (2008). The ideology of home ownership: homeowner societies and the role of housing. Nova York, Palgrave, MacMillan.

ROSTÁS, R. (2014). BR Properties vende imóveis ao grupo GLP por $R \$ 3,18$ bilhões. Valor digital. Disponível em: http://www.valor.com.br/empresas/3450778/br-properties-vende-imoveis-aogrupo-glp-por-r-318-bilhoes. Acesso em: maio 2016.

ROYER L. (2014). Financeirização da política habitacional: limites e perspectivas. São Paulo/Fapesp, Annablume.

SANFELICI, D. (2017). La industria financiera y los fondos inmobiliarios en Brasil: lógicas de inversión y dinámicas territoriales. Economía Sociedad y Territorio, pp. 367-397.

SANFELICI, D. e HALBERT, L. (2015). Financial markets, developers and the geographies of housing in Brazil: a supply-side account. Urban Studies, v. 53, n. 7, pp. 1465-1485.

SANTORO, P. (2014). “Rentabilidade e direito à cidade: uma equação (im)possível?”. In: LAZZARINI, S. (org.). Arq. Futuro: financiamento da inovação urbana: novos modelos. São Paulo, Bei. 
SHIMBO, L. Z. (2010). Habitação social, habitação de mercado: a confluência entre Estado, empresas construtoras e capital financeiro. Tese de doutorado. São Carlos, Universidade de São Paulo. (2012). Habitação social de Mercado. Belo Horizonte, Editora Arte.

UQBAR ANUÁRIO IMOBILIÁRIO (2016). Disponível em: http://www.uqbar.com.br/publicacoes/ anuario-securitizacao-financiamento-imobiliario-2016.jsp\#anuario. Acesso em: 10 abr 2016.

VAN LOON, J. (2014). The financialisation of Dutch real estate: how Real Estate became "just another asset class". Presentation at European Research Council.

Texto recebido em $31 /$ jan/2017 Texto aprovado em 16/maio/2017 
